\title{
GENERAL AND PARTICULAR IN THE ACCOUNTING CONSTITUTION OF THE SOURCES OF THE NATIONAL FOUND OF SOCIAL HEALTH INSURANCES
}

\author{
Lecturer PhD Iuliana Cenar, “1 Decembrie 1918” University Alba Iulia, \\ Email: cenar_iuliana@yahoo.com
}

\begin{abstract}
Among the rights given to the population through the system of State insurance an important role it has the health protection. For this we need resources which can be obtain from the taxes and subsides given by the State. The paper presents the way in which the sources of the National Found of the Health Insurances are accounted and the way the analytical sources are founded through the incomes by using the State reclassification.
\end{abstract}

The growing and modernization of the accounting in the public area is in the concern of the Romanian accounting field, after 1999, Romania started an ample process of accounting harmonize/convergence in order to realize the integration desideratum in the European Union and to bring strange capital investments, the approval of accounting settlements with the Directive IV of European Economics Community and The International Standards of Accounting.

The standards that settles the financialaccounting ${ }^{1}$ field decrees the obligations of public institutions to organize and to lead the incomes accounting and the state expenses, general accounting and the accounting meant for analyze of the programs costs approved, with the purpose to get information overt the incomes and the expenses, the paid, the evolution of the financial situation, patrimony, on the patrimonial surplus/ deficit and also to the opportunity of the financed situations.

We will refer further on to the financial-accounting dimensions of the incomes with supplies the National Found of Social Health Insurance (FNUASS), administrated at a national level by the National Health Insurance and at a territorial level by the District Institutions.

The incomes represent ${ }^{2}$ income taxes, taxes, contributions and other sums income according to the law, and also from the price of the soled assets and work, due to a period of time. The bigger well balanced of the incomes in the field of statement health insurances are the contributions. Those we can consider the price paid for the insurance against the risk of health losses, the insurance has become a social and economic necessity in the life of modern man.

Being made in a statement field the health insurances get the social attribute, this being a way to see the objective reality by the human been.

Social insurances represents complex component, a contributive one of the credit and financial system, based on the obligatory juridical norms, through which the money transfer is realized with the purpose to cover the social risks, including the health risk. Through those the identity of a person is build in the community that she is a part.

Social health insurances represent the principal scheme of financed health population that assures the access to the package of base services for the insurance ones. This has medial services, health services, medicines, health materials, medical devices, and other services that the health insurance people have the right and which is supported from the social health insurances. To deliver

\footnotetext{
${ }^{1}$ Official Monitor no.597 from 17.08.2002, Legea finantelor publice no. 500/2002, art. 74, and Official Monitor no. 48 from 14.01.2005, Legea contabilitatii nr. 82/1991, republished, art.2, alin2.

${ }^{2}$ Official Monitor no.1176 encore from 29.12.2005, O.M.F.P. no. 1917 from 12.12.2005.
} 
the package of base services by the physical and juridical persons authorized by the Ministry of Public Health.

The mechanism of public health insurances "covers" the entire population and because of the principle of social solidarity, it orientates the contributions to the reference at the individual income (not at the personal risk).

The objectives of the social health insurances, given through the legal laws, are: accident;

○ The protection of the insured persons by the costs of medical services in case of illness or

○ To insure the protection of the insured persons in a universal way, fair, undiscriminating under the conditions of the efficient using of the National Found of Social Health Insurance.

The National Found of Social Health is made by the next sources:

- The contributions of physical and juridical persons;

- Subsides given by the State;

- Profits, donations, incomes obtained from the exploitation of CNAS patrimony and the insurances houses, other incomes.

- Sums from the own income of the Ministry of Public Health.

The gathering of contributions from the juridical and physical persons which has the attribute of employer is made by the Ministry of Public Finance, through The National Authority of Fiscal Management (ANAF) in the unique account opened on the National Found of Social Health Insurance. The gathering of contributions from the physical persons, others then the ones for the gathering of incomes made by the ANAF, is done by the insurances houses.

Juridical and physical persons to which is developed the insurance activity have the obligation to calculate and to transfer a contribution of $6 \%$ from the salaries owed for the health insurance to the personal from that unit. The salary found represents the total sums used by a physical or juridical person for the payment of the salary rights or assimilated to the salaries (including the temporal incapacity of work).

The month contribution of the person insured represent $6.5 \%$ which applies to the next categories of incomes:

a) incomes from the salaries or from the assimilated salaries submissive on the incomes;

b) taxable incomes made by persons that have an independent activity (if this income is the only one on which the contribution is calculated, this can not be lower than the one calculated to a base gross proceed in the country, monthly);

c) incomes from the agriculture subdued to the taxes on the incomes and the incomes from the forestry for the physical persons that does not have the quality of an employer;

d) unemployment compensations;

e) incomes from the given assets, incomes from the dividends and interests, incomes from the right of intellectual proprieties made in individual way or in association way and other incomes subdued to the income tax, only in the case in which it does not realize incomes like the mentioned ones, but not less than a minimal base gross proceed in the country, monthly;

f) incomes from the alimonies. The owned contribution applies (at January the 1,2008), only to the incomes from the alimonies that overrun the imposed limit of taxes / income 900 lei and it is calculated for the difference between the alimony quantum and the limit of it.

The obligation to transfer the contribution of social health insurance comes to the juridical and physical persons that pays the insured person or makes the incomes mentioned previous.

For the persons that have the quality of insure person, but does not have the obligation to pay the contribution to the social health insurances, this is sustained by the next budgets:

$\Rightarrow$ state budget for persons that:

- satisfy the military service on time;

- are in the maternity leave till the age of 2 years of the baby and in the case of an child with handicap, till the age of 3 years of this; 
- has a private punishment or has a imprisonment before trial; identification;

- they are retuned or expulsed or are victims of person traffic and are in the process of

- pensioners, for the incomes that are to the limit given by the income tax;

$\Rightarrow$ Social State Budget of insurances, for the persons that have the incapacity to work temporary, given because an accident of work or any professional work; indemnity;

$\Rightarrow$ Unemployment budget of insurances, for the persons that have the unemployment

$\Rightarrow$ Local budgets, for the persons that are a part of a family that has the right to a social help, according to the law regarding the minimal insured income.

A special importance in the realization of the income accounting it is the budgetary classification of those, namely the classification of those after précised criterions on chapters and subchapters.

We present in the table below the way in which the incomes that make the financial sources are structured for medical assistance:

\section{The classification of the incomes due to the budget of National Found of Social Health Insurance}

Table nr.1

\begin{tabular}{|c|c|c|}
\hline Chapter & $\begin{array}{c}\text { Subcha } \\
\text { pter/ } \\
\text { Paragraph }\end{array}$ & Incomes naming \\
\hline & & INSURANCES CONTRIBUTIONS \\
\hline \multirow[t]{5}{*}{20.05} & & The employee contributions \\
\hline & 20.05 .03 & Contributions of Social Health Insurances owed to the employees \\
\hline & 20.05 .03 .01 & $\begin{array}{l}\text { Contributions from juridical and physical persons, that employs } \\
\text { persons }\end{array}$ \\
\hline & 20.05 .03 .02 & $\begin{array}{l}\text { Contributions for the social health insurances due tot the persons } \\
\text { unemployed }\end{array}$ \\
\hline & 20.05 .03 .03 & $\begin{array}{l}\text { Incomes from the debts capitalized by the Authority for the State } \\
\text { Assets Capitalized }\end{array}$ \\
\hline \multirow[t]{6}{*}{21.05} & & The insurances contribution \\
\hline & 21.05 .03 & $\begin{array}{l}\text { Contributions of social health insurances owed by the insured } \\
\text { persons }\end{array}$ \\
\hline & 21.05 .03 .01 & $\begin{array}{l}\text { The contribution of the insured one that have the quality of } \\
\text { employees }\end{array}$ \\
\hline & 21.05 .03 .02 & The contribution owed by other persons \\
\hline & 21.05 .05 & Facultative contributions of the insured persons \\
\hline & 21.05 .50 & $\begin{array}{l}\text { Other contributions for the social insurances owed by the insured } \\
\text { persons }\end{array}$ \\
\hline \multirow[t]{3}{*}{42.05} & & Subsides given by the State \\
\hline & 42.05 .22 & $\begin{array}{l}\text { Health insurances Contributions for the persons that make the } \\
\text { army }\end{array}$ \\
\hline & 42.05 .23 & $\begin{array}{l}\text { Health insurances contributions for the persons that has a private } \\
\text { punishment or has a imprisonment before trial }\end{array}$ \\
\hline \multirow[t]{3}{*}{43.05} & & Subsides from other managements \\
\hline & 43.05 .05 & $\begin{array}{l}\text { Contributions of social health insurances for persons that are in } \\
\text { medical leave or in the medical leave for a ill child in age under } 7 \\
\text { years }\end{array}$ \\
\hline & 43.05 .06 & $\begin{array}{l}\text { Contributions of social health insurances for persons that are in } \\
\text { medical leave because an accident of work or professional illnesses }\end{array}$ \\
\hline
\end{tabular}


The way in which the accounting is reflected in a Local Health Insurance house that generates budgetary debts of incomes are:

- the registered contributions of juridical and physical persons that employees personal:

\begin{tabular}{c}
\hline $\mathbf{4 6 6 5 . 2 0 . 0 5 . 0 3 . 0 1}$ \\
Debts of the National Found of Social \\
Health Insurances Budget
\end{tabular}

\begin{tabular}{c}
$\mathbf{7 4 5 3 . 2 0 . 0 5 . 0 3 . 0 1}$ \\
The contributions of the employees for the Social \\
Health Insurances. Contributions from the juridical \\
and physical persons that have emp loyees \\
\hline
\end{tabular}

The signification of the numerical symbol of the income account is:

7453 - The contributions of the employee for the social health insurances

20.05 - the budgetary chapter entitled The Contributions of Employees employees

20.05.03 - budgetary subchapter Contributions of social health insurances owed by the employees

20.05.03.01 - paragraph Contributions from the juridical and physical persons that have

- the registration of other contributions owed by the employers (for the persons unemployment, for holidays and indemnities, including the persons unemployed):

\begin{tabular}{c}
\hline $\mathbf{4 6 6 5 . 2 0 . 0 5 . 0 3 . 0 2}$ \\
Debts of the National Found of Social \\
Health Insurances Budget \\
\hline
\end{tabular}

\begin{tabular}{c}
\hline $\begin{array}{l}\mathbf{7 4 5 3 . 2 0 . 0 5 . 0 3 . 0 2} \\
\text { The contributions of the unemployed persons for the } \\
\text { Social Health Insurances }\end{array}$ \\
\hline
\end{tabular}

Social Health Insurances

Making evident the contributions owed by the insured persons that are employees

\begin{tabular}{c}
\hline $\mathbf{4 6 6 5 . 2 0 . 0 5 . 0 3 . 0 1}$ \\
Debts of the National Found of Social \\
Health Insurances budget \\
\hline
\end{tabular}

\begin{tabular}{c}
\hline $\begin{array}{c}\mathbf{7 4 6 3 . 2 0 . 0 5 . 0 3 . 0 1} \\
\text { The contributions of the insured persons that have } \\
\text { are emp loyees }\end{array}$ \\
\hline
\end{tabular}

7463 - The contributions of the insured ones for the social health insurances

21.05 - budgetary chapter entitled the insured persons contribution

21.05.03 - budgetary subchapter: contributions of social health insurances owed by the insured persons

21.05.03.01 - paragraph the contribution owed by the insured persons that are employees

- the budgetary debts for the physical persons that are authorized and to the pensioner is registered like this:

$\begin{gathered}\mathbf{4 6 6 5 . 2 1 . 0 5 . 0 3 . 0 2} \\ \begin{array}{c}\text { Debts of the National Found of Social } \\ \text { Health Insurances budget }\end{array}\end{gathered}$
$\begin{gathered}\text { 4665.20.05.03.04 } \\ \begin{array}{c}\text { Debts of the National Found of Social } \\ \text { Health Insurances budget }\end{array}\end{gathered}$
$\begin{gathered}\text { - the debts registration represented by the contributions of health insurances debt by the } \\ \text { - The contributions owed by the pensioners }\end{gathered}$




\begin{tabular}{c}
\hline $\mathbf{4 6 6 5 . 4 2 . 0 5 . 2 2}$ \\
Debts of the National Found of Social \\
Health Insurances budget
\end{tabular}

7721.42.05.22
Subsides from the state budget. Contributions of
health insurances for persons that satisfy the military
service on time

- the recognition of the debts from the budgets (for persons in medical leave of a child, or medical leave because an accident of work or professional ill, persons that benefits from the social help).

\begin{tabular}{c}
$\mathbf{4 6 6 5 . 4 2 . 0 5 . 0 5}$ \\
$\begin{array}{c}\text { Debts of the National Found of Social } \\
\text { Health Insurances budget }\end{array}$ \\
\hline $\begin{array}{c}\mathbf{4 6 6 5 . 4 2 . 0 5 . 0 6} \\
\text { Debts of the National Found of Social } \\
\text { Health Insurances budget }\end{array}$ \\
\hline 4665.42.05.11 \\
\hline Debts of the National Found of Social \\
Health Insurances budget
\end{tabular}

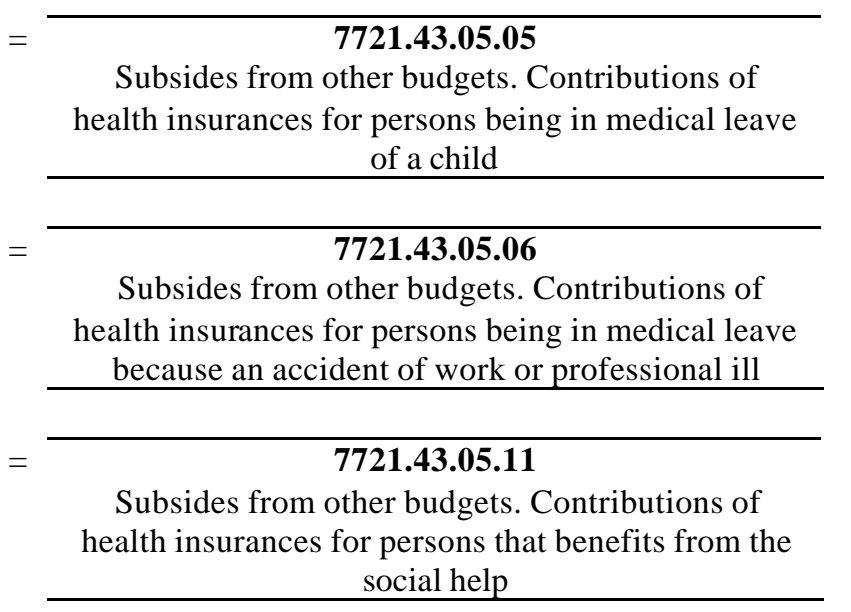

1.640

Subsides from other budgets. Contributions of persons being in medical leave
of a child

Receiving the budgetary debts from through the account opened to the Treasury is supposed to debit the account 5711 "Available from the current incomes of the National Found of Social Insurances" and to credit the accounts with the help of those that has been recognized as budgetary debts 466 "Debts of the National Found of Social Health Insurances Budget" with analytics specified previous.

The accounting of public institutions is a segment of the accounting that is not dissected in the specialty literature where the elements of public finance feels, where the analytical accounting of the budgetary incomes is codified after the rules established nominal (The Ministry of Public Finance). We meet those characteristic also in the institutions that manages National found of social health insurances.

As we can observe, the symbol of the synthetically plan of the accounts valuable for the public institutions have a special found to which we put the numerical symbols for the codification of the chapters and subchapters of incomes imposed through budgetary classification.

\section{Conclusions}

The development degree of social health insurances is influenced by objectives factors such as: the level of gowing in a country, the material possibilities of the peoples and the subjective factors such as: the settlement in the insurance field, the ways in which the societies of insurances offer the insurances that are available, attractive.

The presentation aspects allow us to make some conclusions with general character, namely:

- at the base of organization and management of accounting there are some arrangements in order that the fluxes of liquidities coexists with right of patrimony nature

- the syntactical accounting is replaced by the analytical accounting

- there is a schedule of accounts.

Specific tot the public institutions, and to the social health insurances we notice:

- Unlike to the to the non-financial entities that have the goal to obtain profit, the analytical accounting "of the budgetary incomes and expenses" is not in the scope of the economic agent function of the specific aspect and necessity, but is imposed through the juridical laws in order to assure of the budgetary incomes in order to facilitate of some indicators at macroeconomic level 
- also, respecting the comparison subjects, in the first budgetary case, as an instrument of planning is neglected and the role of the prevision accounting, in the second case represents the principal ax for the achievement of budgetary accounting

- containing the series of substitutions we can affirm that: (i) the budget has the role to assure the connection between the past with present and tot appreciate the way it were made the previous estimations, (ii) there is severity regarding the budget, in which we find a codifying structure of the incomes and expenses, (iii) the budgetary executions is strictly supervised.

The accounting tends to become a complex field confronted with lots of challenges and opportunities. The general objective of accounting is the convergences of the international accounting standards with the purpose to create a common accounting language. This objective is can generate a series of positive ${ }^{3}$ aspects such as: the economic approach in obtaining and processing of accounting information in the juridical rational detriment, improving the volume and the quality of the information given by the financial situations, the privileged external users of the accounting information.

\section{Bibliography:}

Cenar I., Contabilitatea asigurarilor în sistemul de pensii din România, Printing House Casa Carti de Stiinta, Cluj-Napoca, 2006.

Dascalu C., s.c., Convergenta contabilitatii publice din România la Standardele Internationale de Contabilitate pentru Sectorul Public, Printing House CECCAR, Bucuresti, 2006.

Pop A., Abordari normative actuale în contabilitate, International Conference - Audit si convergenta contabila, Printing House Sincron, Cluj Napoca, 2004.

Official Monitor no. 1176 encore from 29.12.2005, Ordinul Ministrului Finantelor Publice 1917 from 12.12.2005 pentru aprobarea Normelor metodologice privind organizarea si conducerea contabilitatii patrimoniului institutiilor publice, a planului de conturi pentru institutii publice si a monografiei privind înregistrarea în contabilitate a principalelor operatiuni.

Official Monitor no. 48 from 14.01.2005, Legea contabilitatii $n r .82 / 1991$, republicata.

Official Monitor no. 1186 encore from 27.12.2005, Ordinul Ministrului Finantelor Publice no. 1954 din 16.12.2005 pentru aprobarea pentru aprobarea Clasificatiei indicatorilor privind finantele publice.

Official Monitor no. 597 from 17.08.2002, Legea 500/2002 privind finantele publice.

Law no. 95 from 4.04.2006 privind reforma în domeniul sanatatii, Official Monitor no. 372 from 28.04.2006.

\footnotetext{
${ }^{3}$ A. Pop, Abordari normative actuale în contabilitate, International Conference - Audit si convergenta contabila, Printing House Sincron, Cluj Napoca, 2004, p.73.
} 
